\title{
Improving Lecturers' Scientific Publication through Capacity Building Moderation
}

\author{
Fadma Yulianti ${ }^{1}$, Fakhry Zamzam ${ }^{2, *}$, Havis Aravik ${ }^{3}$, Luis Marnisah ${ }^{4}$, Tien Yustini ${ }^{2}$, Chandra Satria $^{3}$, \\ Ahmad Sanmorino 5 \\ ${ }^{1}$ Sekolah Tinggi Ilmu Ekonomi Indonesia (STEI), Indonesia \\ ${ }^{2}$ Graduate School, Universitas Indo Global Mandiri, Indonesia \\ ${ }^{3}$ Sekolah Tinggi Ekonomi dan Bisnis Syariah Indo Global Mandiri (STEBIS IGM), Indonesia \\ ${ }^{4}$ Faculty of Economics, Universitas Indo Global Mandiri, Indonesia \\ ${ }^{5}$ Faculty of Computer Science, Universitas Indo Global Mandiri, Indonesia
}

Received June 19, 2020; Revised August 22, 2020; Accepted September 11,2020

\section{Cite This Paper in the following Citation Styles}

(a): [1] Fadma Yulianti, Fakhry Zamzam, Havis Aravik, Luis Marnisah, Tien Yustini, Chandra Satria, Ahmad Sanmorino, "Improving Lecturers' Scientific Publication through Capacity Building Moderation," Universal Journal of Educational Research, Vol. 8, No. 11B, pp. 6014 - 6021, 2020. DOI: 10.13189/ujer.2020.082237.

(b): Fadma Yulianti, Fakhry Zamzam, Havis Aravik, Luis Marnisah, Tien Yustini, Chandra Satria, Ahmad Sanmorino (2020). Improving Lecturers' Scientific Publication through Capacity Building Moderation. Universal Journal of Educational Research, 8(11B), 6014 - 6021. DOI: 10.13189/ujer.2020.082237.

Copyright $\subseteq 2020$ by authors, all rights reserved. Authors agree that this article remains permanently open access under the terms of the Creative Commons Attribution License 4.0 International License

\begin{abstract}
This study aims to get the analysis result of organizational climate, punishment and reward, and competence have an effect on the capacity building of the lecturers in writing scientific papers partially and simultaneously, the organizational climate, punishment and reward, competence and capacity building effect lecturers' scientific work productivity partially and simultaneously. The quantitative approach used the confirmatory survey method and it was verification. Data processing was using SEM-Amos, that organizational climate affected the capacity building with CR 3.494>1.96, significance $0.00<0.05$ and termination 0.219 ; punishment and reward affected the capacity building and $\mathrm{CR}$ $2.740<1.96$, the significance $0.006>0.05$ was terminated 0.240 ; competence influenced capacity building with CR $1.992>1.96$, significance $0.046<0.05$ and termination 0.175 ; Simultaneously organizational climate, punishment, and reward, and competence influenced capacity building with a regression coefficient of 0.518 , and so on. The conclusions from this study are The higher education organizations climate that supports the writing of textbooks for completing lectures, the punishment \& rewards for lecturers who carry out research obligations in every semester, competencies that follow the information technology to continue working, the increase of lecturers' capacity building to write books have an impact on the
\end{abstract}

lecturer's performance to write scientific papers.

$\begin{array}{llr}\text { Keywords } & \text { Productivity, Capacity } & \text { Building, } \\ \text { Organizational } & \text { Climate, Punishment, } & \text { Reward, } \\ \text { Competence } & \end{array}$

\section{Introduction}

A scientific publication from the lecturers' research is an important part of a private institution as the academic performance in developing knowledge. In addition, it can enhance the name of the country in education quality diplomacy in the international arena. Taken from the Scimago Lab's scientific publication ranking site, it was reported that based on International Scientific Publications 1996-2017, Indonesia ranked 52 out of 239 world countries and ranked 11 out of 33 countries in Asia. From this scientific publication ranking information, Indonesia's international reputation is still not encouraging.

In fact, there are many factors that influence lecturers' scientific works publication, starting from the lack of scientific work appreciation, the lack of reward and punishments, the capacities of human resources, financial support from institutions, not conducive academic work 
environment, and English mastery needs to improve.

The results of the preliminary observations found that the phenomenon of problems such as lecturer productivity in making textbooks are still low, there are not many lecturers conduct research, there are not many lecturers who have successfully published journal articles and lecturers who write cite books are very limited. So the capacities of lecturers to write textbooks need to improve, the abilities of lecturers to publish journals has not been a source of pride, because institutional support to lecturers still not been encouraging, there are not many lecturers who have succeeded in getting research grants and get textbook grants, institutional support for lecturer research funding is still being questioned, also, limited time for the lecturers to write books, limited financial funding support in printing textbooks and not many institutions offer rewards to lecturers who excel in obtaining books.

There is no institution that requires lecturers to write textbooks and there is no punishment for lecturers who have not done research and service. Student interest in buying lecturer textbooks is still low, and the competencies of lecturers in making scientific work is questionable. Lecturer working time concentrates more on teaching and the data of lecturer productivity in writing textbooks in South Sumatra is exposed as follows (Table 1):

Table 1. Lecturer productivity in writing textbooks in South Sumatera

\begin{tabular}{|c|c|c|c|c|}
\hline No & Private Universities & Lecturer & Book & \% \\
\hline 1 & UIGM & 180 & 38 & 21.11 \\
\hline 2 & UPGRI & 506 & 34 & 6.71 \\
\hline 3 & UBIDAR & 249 & 22 & 8.87 \\
\hline 4 & UMP & 557 & 42 & 7.54 \\
\hline 5 & UTP & 240 & 7 & 2.91 \\
\hline 6 & UNIKA & 122 & 4 & 3.27 \\
\hline
\end{tabular}

The description from the table above shows that the highest productivity of lecturers in private institutions in South Sumatra in writing books is 21.11 percent, and the lowest is 2.81 percent. From the early surveys on a number of private institutions in South Sumatra, the obtained data shows that not many private institutions provided rewards and punishments, the organizational climate in private institutions has not supported lecturer productivity yet, and the competencies of writing scientific papers were still being questioned. From the phenomena above, it becomes interesting to study more deeply. The researcher will check the low capacity and productivity of lecturers writing scientific papers by using the human resource management science approach.

From the phenomenon of the research problem above, this research is specifically aimed as follows;

A. To get the analysis result of the organizational climate, punishment and reward, and competence in the capacity building of the lecturers in writing scientific papers partially and simultaneously.
B. To get the analysis result of the influence of organizational climate, punishment \& reward, competence and capacity building on lecturers' scientific work productivity partially and simultaneously.

\section{Materials and Methods}

\subsection{The Concept of Productivity Variables}

The productivity variable in this study is the output produced from the same comments or that the comments used more to get the same output. As a result of better productivity is a valuable measure of how well resources used in society. That means fewer comments needed to produce output, less waste, and better conservation of the resources [1]. The rationalization of productivity variables in research refers to certain opinions [2] includes (a) Motivation, (b) work discipline, (c) work ethic, (d) skills, and (d) education.

\subsection{The Concept of Capacity Building Variables}

Capacity building variables in this research are ability, skills, understanding, attitudes, values, relationships, behavior, resources, and conditions that enable each employee, organization, network, and system to carry out their functions to do set goals. The rationalization of capacity building variables is described by several indicators that refer to Steers Richard [3] i.e. (a) knowledge, (b) ability and (c) purpose.

\subsection{The Concept of Organizational Climate Variables}

Organizational climate variables are internal work environments that were influenced by the external environment relatively and continuously so that the work atmosphere, either directly or indirectly will affect the pattern of work relationships, work communication patterns, and comfortable work. The organizational climate variable rationalization in this study refers to Wirawan's [4] opinion, comprising the dimension: (1). The state of the physical environment with indicators of (a) working environment condition and (b) working facilities and infrastructure support. (2). The dimension of the social environment that consists of indicators: (a) working environment, (b) creativity appreciation, (c) mutual trust. And (3) dimensions of the management system which indicators consist of (a) working leadership, (b) Operating procedure standard, (c) the decision-making process, (d) working conflict management, and (e) organizational characteristics.

\subsection{The Concept of Punishment and Reward Variables}

Punishment and reward are the sanctions that given for 
not doing something intentionally with the aim of providing better future effects. The synthesis of reward as a form of appreciation to get a professional workforce according to job demands needed to carry out tasks effectively and efficiently. Punishment \& reward working variables are in the form of indicators as follows: (a) Warning, (b) working termination, (c) getting no bonus, and (d) not being able to get a promotion. The rewards indicators are (a) appreciation, (b) promotion, and (c) Funding [5].

\subsection{The Concept of Competency Variables}

The competency variable in this study is consists of knowledge, skills, values, and attitudes that reflected in the habits of thinking and doing the action. Competence used to describe professional abilities to prove knowledge and conceptualization at a higher level. This competency obtained through education, training, and other experience according to the level of competence. The competency variables in this study based on Wiarah [6] is (a) flexibility, (b) information seeking, (c) the reason, (c) learning ability, (d) achievement, (e) collaboration, and (f) customer service orientation. The flowchart of path model research as follows (figure 1):

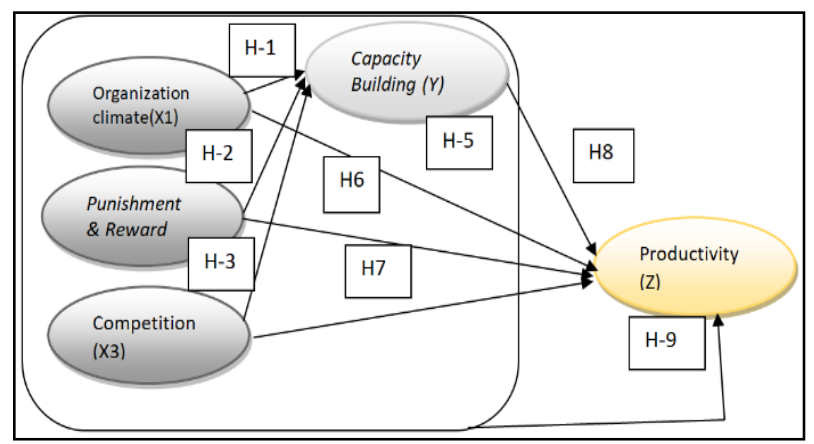

Figure 1. Theoretical Research Flow Chart

\subsection{The Hypothesis}

A. A positive effect or negative effect from organizational climate, punishments \& rewards, and partial and simultaneous competence on the lecturers' capacity building in writing scientific papers.

B. A positive effect or negative effect of organizational climate, punishment, and reward, partial and simultaneous competence and capacity building on the performance lecturers in writing scientific papers.

This study is a quantitative research by using descriptive survey methods and verification surveys for field data collection and direct information from the sample. if we look at the explanation, this research is an associative study, wherein this study there are related variables and it can affect other variables [7]. The research population consisted of 204 lecturers who were the members of the Association of Lecturers of the Republic of Indonesia organization who joined the PDRI South Sumatra WhatsApp Group; The research the sample was obtained randomly, namely the lecturers of the WhatsApp PDRI group in South Sumatra who was willing to provide answers to the questionnaire online.

\subsection{Data Analysis}

Data analysis work by using Structural Equation Modeling (SEM) tools. Multivariate techniques that combine aspects of multiple regression and factor analysis, estimate a series of simultaneous dependency relationships [8]. Hypothesis testing was done by looking at the output CR $>1.96$ and Output squared multiple correlations.

\subsection{Classical Assumption Testing}

\section{A. Normality Testing}

From the SPSS output in the form of a histogram graph, the research data gives a near-normal distribution pattern. The histogram shows that the regression model has fulfilled the normality assumption.

\section{B. Linearity Testing}

The results of the linearity testing of the exogenous variables to the endogenous variables show that the relationship of all the variables has been $<0.05$, so the exogenous variables have a linear relationship with the endogenous variables. The result of linearity testing shows that the research variables have met the criteria for linearity.

\section{Multicollinearity Testing}

The coefficients of the exogenous variable of the research: $\mathrm{VIF}<10$. Then, all the independent variables of the study do not have multicollinearity. Thus, the regression estimation does not occur multicollinearity.

\subsection{Structural Equation Model Feasibility}

The measurement of the first model has not gotten a fit structural model yet, so based on the theoretical model that has been built-in the study as the structural output model has not yet gotten the Fit model. Based on the Eight Goodness of Fit criteria, only four meet the criteria. The structural overall model has not produced a fit structural model. So, it is necessary to change the index by issuing several loading factors $<0.5$ or linking the index that has a high correlation, to produce a fit the model that meets the criteria. 
After modifying the model produces a structural equation model specification, in the form of the overall last structural model presented in the following diagram (Fig. 2).

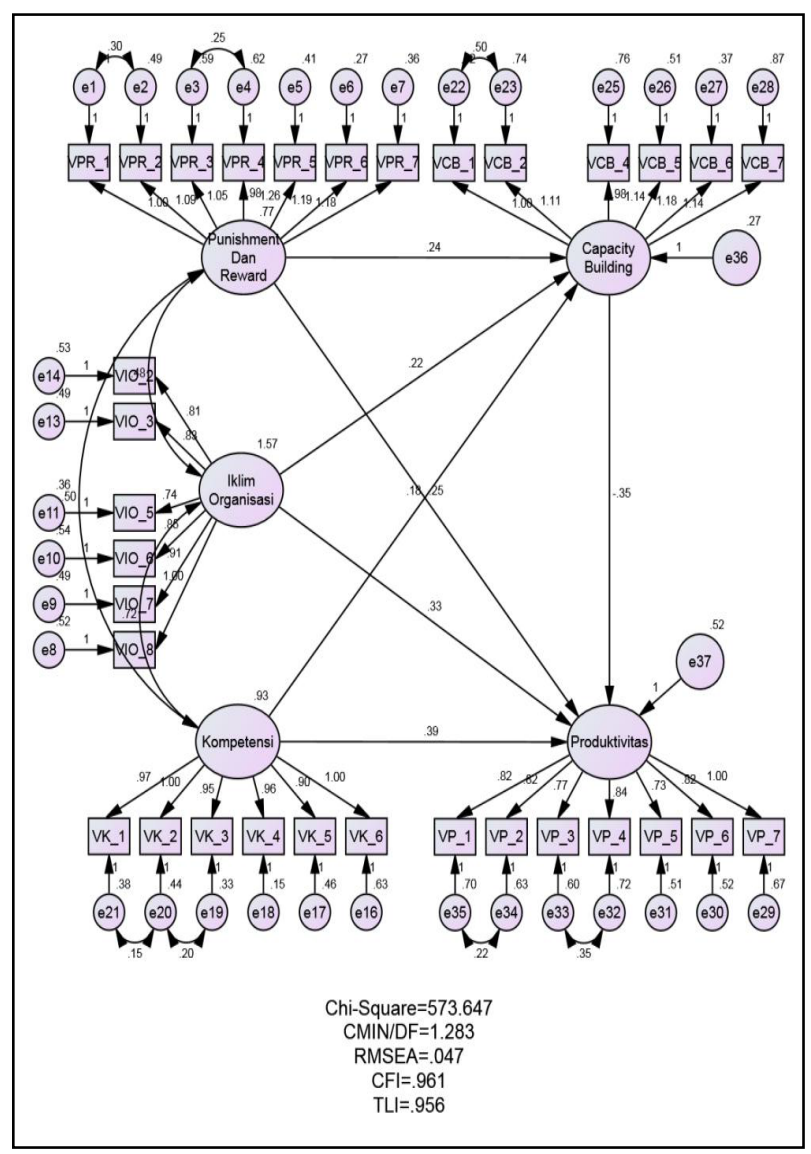

Figure 2. Final Structure Model

Criteria for overall goodness of fit or overall model fit of the goodness of fit as in the following Table 2:
Table 2. Goodness of fit Full Model

\begin{tabular}{|c|c|c|c|c|}
\hline No. & GOF Index & Criteria & Estim. Result & Fit or Not \\
\hline 1 & Chi-Square & $<2$ & 1.205 & Fit \\
\hline 2 & P-Value & $>0.05$ & 0.000 & Not Fit \\
\hline 3 & CFI & $>0.95$ & 0.961 & Fit \\
\hline 4 & TLI & $>0.95$ & 0.956 & Fit \\
\hline 5 & RMSEA & $<0.08$ & 0.047 & Fit \\
\hline 6 & CMIN/DF & $<2.00$ & 1.283 & Fit \\
\hline 7 & DF & $>0.00$ & 447 & Fit \\
\hline 8 & IFI & $>0.90$ & 0.972 & Fit \\
\hline
\end{tabular}

The overall analysis of the structural equation model above has a model that meets the goodness criteria of a fit index. Out of eight criteria for the goodness of fit, it turns out that seven criteria have met the theoretical standard. Thus, the structural equation model is fit and it is continued for further analysis.

To get the size of the effect of exogenous variables simultaneously on endogenous variables, from the squared multiple correlations Output in Table 3:

Table 3. R-Square Value

\begin{tabular}{|c|c|}
\hline Variable & R-Square \\
\hline Capacity Building $(Y)$ & 0.518 \\
\hline Productivity $(\mathrm{Z})$ & 0.478 \\
\hline
\end{tabular}

Table 3 above, squared multiple correlations Output that competency, organizational climate, and punishment $\&$ reward affect capacity building simultaneously 0.518 or 51.8 percent, while competence, organizational climate, punishment \& reward, and capacity building simultaneously influence the productivity of 0.478 percent or 47.8 percent. Furthermore, the characteristic estimation results used to test the hypothesis as the output regression weight structural equations model in the following Table 4:

Table 4. Parameter Estimation and Test of Significance

\begin{tabular}{|c|c|c|c|c|}
\hline Research Model & Estimation & S.E. & C.R. & P \\
\hline Capacity_Building $<<$ Punishment_\&_Reward & 0.240 & 0.087 & 2.740 & 0.006 \\
\hline Capacity_Building << Organisation Climate & 0.219 & 0.063 & 3.494 & $* * *$ \\
\hline Capacity_Building <<Competence & 0.175 & 0.088 & 1.992 & 0.046 \\
\hline Productivity $<<$ Punishment_\&_Reward & 0,254 & 0.122 & 2.080 & 0.037 \\
\hline Productivity << Organisation Climate & 0.328 & 0.092 & 3.574 & $* * *$ \\
\hline Productivity << Competence & 0.392 & 0.126 & 3.111 & 0.002 \\
\hline Productivity <<Capacity_Building & -0.351 & 0.170 & -2.062 & 0.039 \\
\hline
\end{tabular}




\section{Analysis and Discuss}

\subsection{The Analysis of Organizational Climate Influence on Capacity Building}

Hypothesis testing proved that there is a positive and significant influence of organizational climate on capacity building. From the processing data by using SEM-Amos, that CR 3.494>1.96 and the significance level of 0.00 $<0.05$, that there is an influence of organizational climate on capacity building.

This gives an understanding that the more conducive organizational climate in higher education, the more impact on increasing the capacity building of lecturers writing scientific papers. The indicators of organizational climate variables that are most dominant are writing textbooks, supporting lecture activities and the lowest indicator are Lecturers' opportunity in developing intellectual work. In the universities that develop a conducive climate for lecturers to support lecture activities by making textbooks will be able to influence the capacity building of the concerned lecturers, higher education as institutions as well as effective lecture systems.

Same with Surayatika [9], that Organizational climate affected capacity building with t-obtained 3.473>t-table 1.969 and regression of 22.1 percent. The organizational climate of the People's Representative Council Secretariat based on the variables had been in the above good category. The organizational climate-forming indicator of the People's Representative Council Secretariat to conducive is that there is clear regulation on the People's Representative Council fittings authority, the Indicator which becomes the constraint in developing a comfortable organizational climate, is the secretariat of the Secretariat staff in maintaining the working relationship with the People's Representative Council.

\subsection{The Analysis of Punishment \& Reward Effect on Capacity Building}

The effect of punishment $\&$ reward on capacity building is not successfully confirmed in this study, it means that the theoretical research is contrary to the empirical in the field. The results of testing the data processing hypothesis with SEM-Amos is that CR $2.740<1.96$ and Significance $0.006>0.05$, so the effect of punishment \& reward on Capacity Building. It is understandable that the provision of punishment or sanctions to lecturers who write textbooks or the provision of rewards for lecturers who successfully write textbooks can affect the capacity building of the concerned lecturer.

The punishment and reward have been good with a coefficient: 4.2240 , the highest indicator variable Lecturers required to conduct research in each semester and the lowest indicator of Higher Education supports the funding for lecturers to write textbooks. From the description above, requiring lecturers to carry out research in each semester, and obliging to followed up by writing textbooks and providing supporting funds for writing books will increase capacity building in writing scientific papers. Actually, from observations in the field, the dominant reason for increasing the capacity building of lecturers in writing books to send lecturers to attend workshops or book writing training.

\subsection{The Analysis of Competence Effect on Capacity Building}

The competencies of lecturers influence on the capacity building in writing scientific papers, the more relevant scientific competence of lecturers can increase capacity building in writing scientific papers according to their scientific discipline. The results of data processing with SEM-Amos, that CR 1.992>1.96 and Significance of 0.046 $<0.05$, so there is a positive and significant influence of competence on capacity building.

The competency variable has been good with a coefficient: 4.2916, the highest variable is the development of information technology opens opportunities to continue working and the lowest indicator is that the lecturer tries to develop interdisciplinary competencies. it means that lecturers who always follow information technology development, opened to the opportunities in developing scientific work, a lot of information can be taken from the internet such as Google. However, not all lecturers develop multidisciplinary scientific competencies.

\subsection{The Analysis of Organizational Climate, Punishment and Reward, and Compensation Effect on Capacity Building}

The highest competency variable indicator is that the information technology development is beneficial for lecturers to continue working and the lowest indicator is the lecturer trying to develop interdisciplinary competencies. Sub Structural Equations:

Capacity Building $=0.219 *$ organization climate $240 *$ punishment and reward $+0.175 *$ competition + Error var

$$
\text { Capacity Building }=0.518+\text { Error var }
$$

From the structural equation, it is known that the exogenous effect variables of organizational climate, punishment \& reward and competency simultaneously on endogenous capacity-building variables is 0.518 or 51.8 percent. So, 42.1 percent was affected by variations of other variables outside of the study.

\subsection{Analysis of the Effect of Organizational Climate on Productivity}

From the results of processing data by using SEM-Amos that CR $3.574<1.96$ and a significance level of $0.000<0.05$, so that organizational climate affects productivity. The influence of organizational climate on productivity 
successfully confirmed. Organizational climate variables description is not good with a coefficient: 3.6922 , the highest indicator variable is the writing of textbooks supporting lecturing activities and the lowest indicator is that lecturer's less opportunity to develop their intellectual work. While the performance of lecturers is approaching well with a coefficient of 3.946 , the highest indicator is that lecturers are eager to write scientific papers and the lowest indicator is that lecturers have not succeeded in getting the book writing royalties from publishers.

Lenny Hasan's research [14] found that the Reward variable had a positive effect on productivity with t-count $>$ t-table $(6.160>1.666)$ and punishment variable with t-count $>$ $t$ table (4.769>1.666). In line with Aravik [15], the results of his research that there is an effect of punishment and reward on productivity, testing data using t-test that $t$ count $6.215>\mathrm{t}$-table 1.976 and a significance level of $0.00>0.05$. Likewise, in Pertiwi's research [16], based on regression testing, shows that reward and punishment simultaneously influence employee productivity because $\mathrm{f}$ - count $=7.695>$ $\mathrm{f}$-table $=3.252$ and sig. $=0.002<\alpha=0.005$.

\subsection{The Analysis of Punishment \& Reward Effect on Productivity}

The theoretical framework that the punishment and reward can affect the increase of productivity is in line with the results of research that stated that the effect of Punishment \& Reward on Productivity. From the results of data processing by using SEM-Amos, and testing the data that CR $2.080<1.96$ and the significance level of $0.037<0.05$, it can close that there is an effect of punishment and reward on productivity.

The punishment and reward are given by private universities in Palembang to lecturers have a coefficient: 4.2240 , the highest indicator variable is that lecturers are required to conduct research every semester and the lowest indicator is that Universities do not support any funding for lecturers to write textbooks. While the lecturer's performance is approaching well with a coefficient: 3,946. The highest indicator variable is that lecturers are eager to write scientific papers and the lowest indicator is that lecturers have not succeeded in getting book writing royalties from publishers.

There is an obligation for lecturers to conduct research in each semester with punishment $\&$ reward; it can encourage the enthusiasm of lecturers to write scientific papers. The problem faced by lecturers is that not all private institutions in Palembang provide adequate financial support for lecturers who have succeeded in writing books, another impact is that not many lecturers have succeeded in obtaining book writing royalties from publishers.

Lenny Hasan's research [14] found that the reward variable had a significant and positive effect on productivity with $\mathrm{t}$-count $>\mathrm{t}$-table $(6.160>1.666)$ and punishment variable with $\mathrm{t}$-count $>\mathrm{t}$ table $(4.769>1.666)$.
In line with Aravik [15], the results of his research that there is an effect of punishment and reward on productivity, testing data using t-test that $t$ count $6.215>t$-table 1.976 and a significance level of $0.00>0.05$. Likewise, in Pertiwi's research [16], based on regression testing, shows that reward and punishment simultaneously influence employee productivity because f-count $=7.695>\mathrm{f}$-table $=$ 3.252 and sig. $=0.002<\alpha=0.005$.

\subsection{The Analysis of Competence Effect on Productivity}

Competence has effects on productivity as the theoretical framework is in line with the results of the hypothesis, which means that the theoretical framework can confirm so that the theory is in line with the empirical. The hypothesis testing of processing data with SEM-Amos, that CR 3.111> 1.96 and the significance of $0.002<0.05$, then there is the effect of competence on Capacity Building, While the lecturer competencies are good with a coefficient of 4.2916, the highest indicator of lecturer competence is the development of Information technology, which opens opportunities to continue working and the lowest indicator is that lecturers have not developed interdisciplinary multiple competencies yet. The lecturer productivity description is approaching well with a coefficient of 3.946, the highest productivity indicator is that lecturers are eager to write scientific papers and the lowest indicator is that lecturers have not yet succeeded in getting book writing royalties from publishers.

The technology and information used by lecturers to open the opportunities for lecturers to continue working; this condition encourages higher lecturer productivity to write scientific papers. On the other hand, there is still a lack of lecturers to try to develop interdisciplinary scientific competencies; it much impacts the lecturer's achievement for writing quality books to get royalties from publishers.

Aravik [12] concluded that competence affects productivity as well as the results of hypothesis testing using the $\mathrm{t}$-test that $\mathrm{t}$-count is $4.044>$ with $\mathrm{t}$-table 1.976 and the significance level is $0.00<0.05$. Rismawati [17] mentions that there is a positive influence of 0.528 between employee work competencies and work productivity with a percentage of 27.9 percent.

\subsection{The Analysis of Capacity Building Effect on Productivity}

Capacity Building has affected the lecturer's performance in writing scientific papers, increasing the capacity building of personal linear lecturers by increasing productivity in writing scientific papers. From the results of data processing with SEM-Amos, that CR-2.02>1.96 there is a negative and significant influence of $0.039<0.05$, then in the study, it can conclude that capacity building has a negative effect on productivity. 
The Description of the capacity building of new lecturers is heading well with a coefficient 3.7748 , while the highest indicator of capacity building is the Lecturer trying to increase the capacity to write books and the lowest indicator is a coefficient 3.2197 i.e. the scientific work of lecturers has received Intellectual Property Rights.

The Description of lecturers' productivity is approaching good criteria with the Regression of 3,946, the highest productivity indicator is that lecturers are eager to write scientific papers and the lowest indicator is that lecturers have not yet succeeded in getting book writing royalties from publishers. The number of scientific papers publications is one indicator of lecturer performance in a higher learning institution [18].

\subsection{The Analysis of Organization Climate, Punishment and Reward, Competence, and Capacity Building Effect on Productivity}

From the theoretical framework, all in punishment and reward, organizational climate, competence, and capacity building simultaneously affect productivity; empirical is in line with the theoretical framework [19]-[23]. The results of processing data by using SEM-Amos show that the output on Squared multiple correlations R-square the regression coefficient is 0.478 , and then there is a positive and significant effect of punishment and reward, organizational climate, competence and competence on Productivity.

The analysis result using structural equation shows the organizational climate, punishment \& reward, competence and capacity building together on productivity are:

$$
\begin{gathered}
\text { Productivity }=0.328 * \text { organization climate }+0.254 * \\
\text { punishment and reward }+0.392 \text { competition }-0.351 * \\
\text { capacity building }+ \text { Error var } \\
\text { Productivity }=0.478+522 * \text { Error var }
\end{gathered}
$$

Whereas the exogenous effect on the independent variable of productivity is 0.328 for organizational climate, punishment, and reward is 0.254 , competence is 0.392 , and capacity building is -0.351 . So to improve the lecturer's performance, it is better to increase the lecturer's competencies in writing scientific papers.

The organizational climate, punishment \& reward, and competency effect through capacity building moderating variables is not as significant as in Table 5:

Table 5. The Effect of $X$ on $Z$ through Moderation $Y$

\begin{tabular}{|c|c|c|c|}
\hline Variable & Competence & $\begin{array}{c}\text { Organization } \\
\text { Climate }\end{array}$ & $\begin{array}{c}\text { Punishment \& } \\
\text { Reward }\end{array}$ \\
\hline Productivity & -0.061 & -0.077 & -0.084 \\
\hline
\end{tabular}

\section{Conclusion}

From the results of the analysis and discussion, the conclusions from this study shown as follows:
A. The higher education organizations climate that supports the writing of textbooks for the completeness of lectures, the punishment - rewards for lecturers conducting research in each semester, the competencies of lecturers after the information technology to continue to work much encourage lecturers to try to increase the capacity to write books.

B. The higher education organizations climate that supports the writing of textbooks for completing lectures, the punishment $\&$ rewards for lecturers who carry out research obligations in every semester, competencies that follow the information technology to continue working, the increase of lecturers' capacity building to write books have an impact on the lecturer's performance to write scientific papers.

Managerial Implications:

A. In improving the capacity building of lecturer writing scientific work by increasing the competencies of lecturers in writing scientific papers, and then a conducive good academic atmosphere so that lecturers will be creative.

B. The strategy to increase lecturer productivity in making scientific work by increasing lecturers' competence in writing scientific works such as being sent to attend teaching textbook workshops and research methodologies.

\section{REFERENCES}

[1] Wibowo. (2014). Manajemen Kinerja, Jakarta: PT. Raja Grafindo Persada.

[2] Sedarmayanti. (2011). Manajemen Sumber Daya Manusia, Reformasi Birokrasi dan Manajemen Pegawai Negeri Sipil, Cetakan Ke Empat, Jakarta, Penerbit PT Refika Aditama

[3] Steers Richard. M. (2005). Efektivitas Organisasi. (Terjemahan). Jakarta: penerbit Erlangga.

[4] Wirawan. (2007). Budaya dan Iklim Organisasi: Teori Aplikasi dan Penelitian. Jakarta: Salemba Empat.

[5] Kurniawan, H, Muh. Mukeri, W and Aziz, F. (2016). Pengaruh Reward, Punishment, Beban Kerja dan Pelatihan Terhadap Produktivitas Kerja Karyawan; Studi Kasus Pada Karyawan PT. Andalan Arthalestari Semarang, Journal of Management, Volume 2 No.2 Maret 2016.

[6] Manik, W.E. (2014). Pengaruh Kompetensi Dan Kompensasi Terhadap Kepuasan Kerja Serta Implikasinya Pada Kinerja Paramedis Di Rumah Sakit Cibabat Kota Cimahi. Jurnal Ekonomi, Bisnis \& Entrepreneurship. Vol.8, No.2 h:62-72 (Oktober). ISSN 2443-0633.

[7] Sekaran, U. (2003). Research Methods for Business, Shoutern Illinois University at Carbondale.

[8] Hair, et al. (2014). Multivariate Data Analysis, New International Edition., New Jersey: Pearson. 
[9] Zamzam, F, Susanto, Y and Surayatika, D. (2017). The Capacity Building of the Regional Representatives' Council Secretariat in South Sumatera, Proceeding 3rd Sriwijaya Economics, Accounting, and Business Conference 2017, ISBN 979-587-703-8.

[10] Romli, A, Zamzam F. (2017). Analisis Pengaruh Iklim Organisasi Terhadap Kinerja Dan Produktivitas Legislasi Daerah Provinsi Sumatera Selatan, Jurnal Media Wahana Ekonomika, Vol. 14, No.2, Juli 2017: 56-64.

[11] Sukarman K. (2012). Pengaruh Iklim Organisasi Terhadap Produktivitas Kerja Pegawai Di Sekretariat Daerah Kota Gorontalo, Jurnal Inovasi Volume 9, No.1, Maret 2012 ISSN $1693-9034$

[12] Aravik, H. (2018). Tesis, Pengaruh Punisment \& Reward, Iklim Organisasi Dan Kompetensi Terhadap Produktivitas Karya Ilmiah Dosen Anggota Group Whatshup PDRI Provinsi Sumatera Selatan; Program Magister Manajemen UIGM Palembang.

[13] Musbandi, A., Wahyudi, Hm. Chiar. (2017). Pengaruh Iklim Organisasi Dan Motivasi Kerja Terhadap Produktivitas Kerja Pegawai Dinas Pendidikan Kabupaten Sambas; Tesis, Program Studi Magister Administrasi Pendidikan, Fakultas Keguruan Dan Ilmu Pendidikan Universitas Tanjungpura Pontianak.

[14] Saputra, D., Nurlina, Hasan, L. (2016). Pengaruh Reward Dan Punishment Terhadap Produktivitas Kerja Karyawan PT. Kereta Api Indonesia (Persero) Divisi Regional II Sumatera Barat, Penelitian, Universitas Tamansiswa Padang.

[15] Aravik, H., Zamzam, F. (2017). Manajamen SDM Berbasis Syariah, Bogor: RWTC Succes.

[16] Pertiwi, N.R. (2017). Pengaruh Program Punishment Dan
Reward Dalam Meningkatkan Produktivitas Kerja Pegawai Menurut Perspektif Ekonomi Islam (StudiPada BPJS Ketenagakerjaan Bandar Lampung); Tesis, Fakultas Ekonomi Dan Bisnis Islam Universitas Islam Negeri Raden Intan Lampung.

[17] Sundarsih, D., Rismawati, E. (2017). Pengaruh Kompetensi Karyawan Terhadap Produktivitas Kerja PT Sinarmas Multifinance Cabang Banjar; J-POLITRI, Jurnal Bisnis, Keuangan Dan Komputer, ISSN: 2549-9824 Vol. 1 No. 4 Desember 2017 p 11-22.

[18] Sanmorino, A., Ermatita, Samsuryadi. (2019). The Preliminary Results of the Kms Model with Additional Elements of Gamification to Optimize Research Output in a Higher Education Institution, in International Journal of Engineering and Advanced Technology, vol. 8(5), pp. 554-559.

[19] Bahri, S., Zamzam, F. (2014). Model penelitian kuantitatif berbasis SEM-Amos. Yogyakarta: Penerbit Deepublish.

[20] Zamzam, F. (2016). Sinergisme Komitmen Keorganisasian Dan Kompensasi Terhadap Iklim Organisasi Sekretariat DPRD Dengan Moderasi Kinerja Dan Produktivitas Serta Implikasinya Pada Capacity Building, Penelitian, Program Magister Manajemen UIGM Palembang.

[21] Romli, H., Zamzam, F., (2018). The Manajerial and Strategic Implications in Improving Legislation Productivity, International Journal of Economic Research.

[22] Kurniawan, H., Mukeri, M., Fathoni, A. (2016). Pengaruh Reward, Punishment, Beban Kerja, Dan Pelatihan Terhadap Produktivitas Kerja Karyawan (Studi Kasus Pada Karyawan PT Andalan Arthalestari Semarang); Journal of Management, Volume 2 No.2 Maret 2016

[23] Zamzam, F., (2017). Manajemen Iklim Organisasi, Bogor: Penerbit RWTC Succes. 